\title{
Two-Step and Direct Fermentation in the Production of Ethanol from Starch: A Short Review
}

\author{
Endah Retno Dyartanti $^{1, \mathrm{a}}$, Margono ${ }^{1, \mathrm{~b}}$, Anisa Raditya Nurohmah ${ }^{1, \mathrm{c}}$, Shofirul Sholikhatun \\ Nisa $^{1, \mathrm{~d}}$, and Novan Riantosa ${ }^{1, \mathrm{e}}$ \\ ${ }^{1}$ Chemical Engineering Department, Faculty of Engineering, Universitas Sebelas Maret, Surakarta, \\ Indonesia \\ Jl. Ir. Sutami 36A Kentingan, Jebres, Surakarta 57126 \\ E-mail: aendahrd@staff.uns.ac.id (Corresponding author), bmargono@staff.uns.ac.id, \\ canisaradityan@gmail.com, dshofirulnisa@gmail.com, ${ }^{e n o v a n r r 94 @ g m a i l . c o m ~}$
}

\begin{abstract}
Ethanol as a renewable fuel has been widely produced in various countries. One source of raw material for producing ethanol is starch. The process of producing ethanol from starch needs to be pretreated so that starch molecules can split into smaller ones. However, this process requires pre-treatment which will expensive more than ethanol from sugar. There are two types of pretreatment i.e. two-step ethanol production and direct fermentation. There is two kind of hydrolysis, acid hydrolysis, and enzymatic hydrolysis. Twostep ethanol production is a conventional method that separates pretreatment and fermentation process, while direct fermentation is the direct production of starch into ethanol using recombinant yeast that co-produces enzymes such as amylose and glucoamylase. Twostep ethanol production has the advantage of high yield but needs high cost whereas, direct fermentation has the advantage of low-cost production but needs longer time. Common starch to ethanol production consists of two stages, namely hydrolysis of raw materials into glucose and fermentation into ethanol. Both of these processes can be run on average at temperatures of $30-80^{\circ} \mathrm{C}$ with a $\mathrm{pH}$ range of $4-6$ and varying time intervals. The enzyme used depends on the source of the starch, but the most commonly and the best used are $\alpha$-amylase and combination of $\alpha$-amylase.
\end{abstract}

Keywords: Ethanol, starch, pre-treatment

EQUILIBRIUM Volume 4 No.1 July 2020

Online at http:/ / equilibrium.ft.uns.ac.id 


\section{Introduction}

Efforts to replace energy sources from fossil fuels with renewable energy are being actively carried out. This is due to the fact that fossil fuels are non-renewable resources so they are increasingly depleted and the effects of burning fossil fuels cause greenhouse gas emissions which will adversely affect the environment. Current energy scenarios encourage researchers to actively conduct research on non-petroleum, renewable and nonpolluting fuels [1]. One of the fuels that meet the energy scenario criteria is bioethanol. Bioethanol can be produced from various renewable sources. Several countries that have succeeded in producing bioethanol as fuel and have been commercialized are United States, Brazil, European Union, China, Canada, and others as shown in Figure 1 [2].

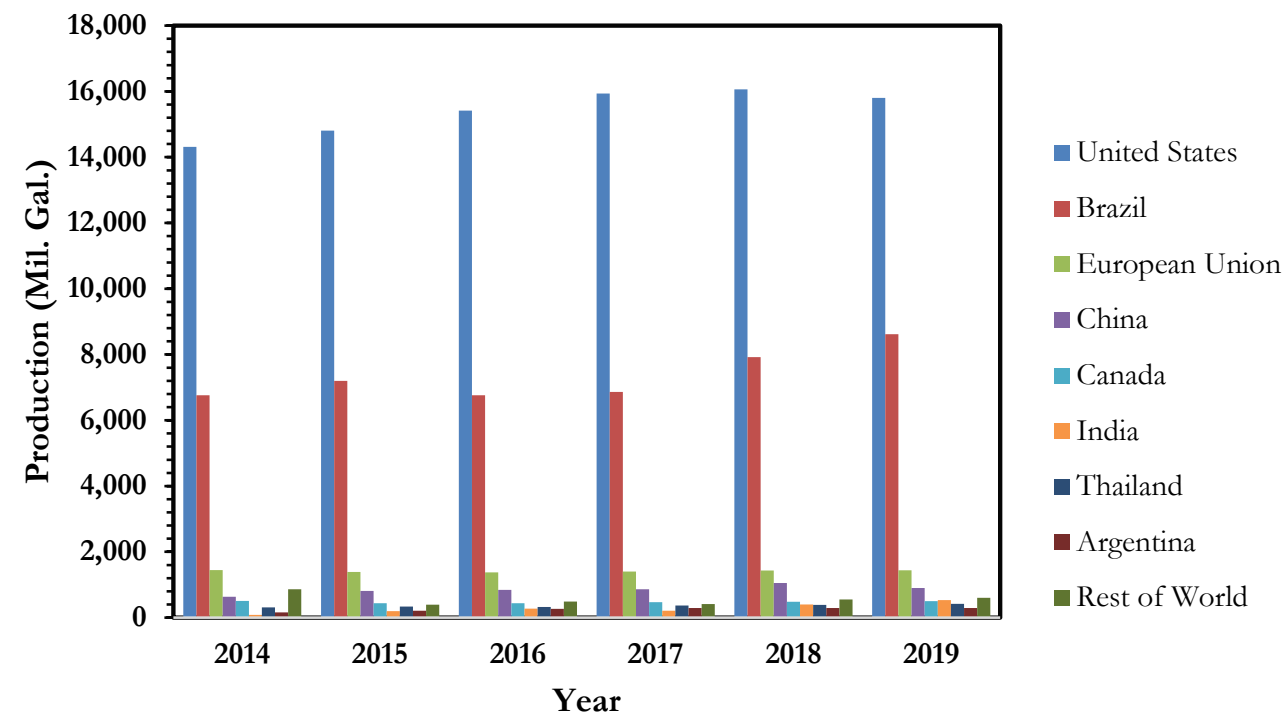

Figure 1. Annual World Fuel Ethanol Production [2]

High ethanol production in some of these countries proves that ethanol can be a promising fuel. Ethanol can be used in transportation and substitute for diesel [3]. Ethanol has a higher octane number than petrol, which has good mixing properties [4]. The higher octane number can make it easier to burn at a higher compression ratio, faster, lower engine knock so it is very beneficial when ethanol is mixed with a petrol [5]. Besides, the presence of ethanol in petrol can reduce $\mathrm{CO}_{2}$ emissions so it is more environmentally friendly [6].

As mentioned above, ethanol can be produced from various renewable sources. These renewable sources can be classified into 3 sources i.e. sugar, starch, and lignocellulose [1]. Sugar sources include sugarcane, sweet sorghum, and sugar beets, starch sources include corn, potatoes, and barley, and lignocellulose sources include perennial grass, aquatic plants, and agricultural residues. Each of these types of sources has different handling in converting to ethanol. Sugar sources can be fermented directly without special pretreatment. Starch sources must be hydrolyzed before fermentation. This hydrolysis process aims to break down polysaccharides into monosaccharides and disaccharides, while lignocellulosic sources need more complex handling so that they can be fermented into ethanol [5].

Ethanol sourced from starch is produced more than other sources [7]. This is because some sources of starch can grow anywhere without being disturbed by climate and soil types [8]. However, the process of producing ethanol from starch requires pre-treatment which will expensive more than ethanol from sugar. Several studies have succeeded in the process of producing ethanol from starch with minimal cost. This review will explain some of the pre-treatment processes in producing ethanol from starch. There are two methods for producing ethanol, i.e. two-step ethanol production and direct fermentation. There are also several examples of starch sources along with operating conditions, enzymes, and hydrolysis efficiency to produce ethanol. 


\section{Discussion}

\subsection{Two-Step Ethanol Production}

Common starch to ethanol production consists of two stages, hydrolysis of raw materials into glucose and fermentation into ethanol. Several studies on the two stages of ethanol production have been carried out [9][14].

In ethanol fermentation, very high gravity (VHG) fermentation is an emerging development of ethanol that has been shown to be environmentally-safe, high conversion, and low-cost. VHG is explained as "developing" because, logically, it is being studied far and wide in the dry-grind process. The benefit of VHG fermentation is a 58\% reduction in the water used in the fermentation process; low chance of bacterial infection due to higher osmotic conditions; improved enzymatic activity due to low starch-to-water ratio, and increased fermentation rate. But this approach has the downside of a lengthy process of fermentation. This fermentation process is often referred to as stuck or slow fermentation. In 2018, Appiah-Nkansah reported ethanol production using sweet sorghum juice prepared with VHG with a ratio of grain sorghum and sweet sorghum juice 1:1. The combination of 109 cells $/ \mathrm{mL}$ inoculation size, fermentation temperature of $30{ }^{\circ} \mathrm{C}$, and $16 \mathrm{mM}$ urea supplementation have a synergistic effect on ethanol production. The results showed that from dissolved solids of $33 \%$ (w/v), 20.25\% (v/v) of ethanol and fermentation efficiency of up to $96 \%$ can be obtained. The results revealed that the sugar content ratio 1-1 of the sorghum grain mixture with sweet sorghum would have the best ethanol results [9].

Li, 2017, was also investigated VHG fermentation. Results showed 20.3\% ethanol production and 84.5\% fermentation efficiency after fermentation for 72 hours and $2 \%$ yeast added. Urea and ammonium are used as yeast additives to minimize the expense of ethanol processing, since they are a low-cost source of nitrogen. The combined ethanol production properties of the three nitrogen sources were calculated using the central composite design (CCD) process. The better concentration of nitrogen supplement $(0.6 \%$ yeast extract, 69 $\mathrm{mM}$ urea, and $26 \mathrm{mM}$ ammonium sulfate) led to comparable ethanol yield and fermentation efficiency relative to those supplemented with $2 \%$ yeast extract, indicating that Saccharomyces cerevisiae synergistically increased ethanol production during VHG urea and ammonium sulfate fermentation [10].

Ajibola, 2012, researched the ethanol production capacities of two forms of cassava with indigenous palm wine yeast varieties, compared with commercial baker's yeast. The production of ethanol from starch has a high yield, with production going through two phases of the process, i.e. hydrolysis and fermentation. The traditional acid catalyst method of starch hydrolysis was used. Currently, enzymes have also been added to the hydrolysis process as catalysts. Enzymatic hydrolysis consists of two steps. The first step, starch suspension and alpha-amylase enzyme catalyst obtained from Bacillus licheniformis, Escherichia coli, or Bacillus subtilis strains should be taken at temperatures $\left(90-110^{\circ} \mathrm{C}\right)$, so that amylase can break down the starch kernel. The second step, saccharification ( $4 \mathrm{ml}$ of amyl glucosidase solution is added to the liquid starch from the liquidation stage). Several factors affect the reaction rate of starch hydrolysis, including the increased concentration of the enzyme, temperature, and time. The cassava starch produced the highest dextrose equivalents at $40^{\circ} \mathrm{C}$. The reaction time also impacts the hydrolysis of cassava starch, as it was examined after $24 \mathrm{~h}$ of hydrolysis that the concentration of reduced sugars enhanced, which could result from a reversal phase [11].

Intaramas et al, 2018, investigated the thermo hydrolysis process of cassava starch under thermo catalytic conditions using an acid catalyst Cassava starch $(20 \mathrm{~g})$ and HA-CC-SO ${ }_{3} \mathrm{H}(12 \mathrm{~g})$ catalyst were subjected to mixed milling. Hydrolysate from thermo hydrolysis was modified to $\mathrm{pH} 5.5$ with $2 \mathrm{M} \mathrm{H}_{2} \mathrm{SO} 4$ and added with yeast extract, peptone, and glucose. The result presented that $\mathrm{CC}-\mathrm{SO}_{3} \mathrm{H}$ successfully cut chains of amylose and amylopectin into smaller chains and released monomers of glucose as the final product of hydrolysis. The thermo hydrolysis of cassava starch with the addition of CC-SO3H catalyst was shown the highest glucose and TRS results were obtained in a short time reaction. In addition, this approach allows for a shorter reaction time than traditional methods. The time required for the process of liquefaction and saccharification of starch was just a few hours with glucose yields and selectivity of nearly $100 \%$. At 96 hours from the thermohydrolysis hydrolysis at $160^{\circ} \mathrm{C}$, the highest ethanol concentration of $15.41 \mathrm{~g} / \mathrm{L}$ was reached for 2 hours [12].

The use of microalgal biomass to produce lipid and starch for transport fuel production presume ready conversion of starch to ethanol. On that method, though, few have shown data. Here, biomass from Chlamydomonas reinhardtii mutant cw 15 wall-deficient cells was treated sequentially at $121^{\circ} \mathrm{C}$ and 2 atm with 
$70^{\circ} \mathrm{C}$ ethanol and $60^{\circ} \mathrm{C}$ hexane before sulfuric acid hydrolysis. The results revealed that they were able to hydrolyse about $30 \%$ of the dry algae. Saccharomyces cerevisiae successfully fermented this hydrolysed starch into ethanol at a maximum concentration of $0.87(\mathrm{~m} / \mathrm{v})$ within 28 hours at a maximum speed of $14 \mathrm{~mL} / \mathrm{g}$ per hour. The ethanol yield coefficient of glucose measured was $0.44(\mathrm{~g} / \mathrm{g})$. This produces ethanol and glycerol in equal amounts [13].

The most used enzymes as stated in Table 1 for two-step ethanol production is $\alpha$-amylase [9], [11]. Amylases are starch hydrolases with a number of amino acid sequences that are strongly conserved among family members.

\subsection{Direct Fermentation}

The production of ethanol from starchy material by enzymatic hydrolysis involves two or three steps and requires improvement to get efficient production at a low cost. High costs on the process are due to starchy must be hydrolyzed at high temperatures $\left(140\right.$ to $\left.180{ }^{\circ} \mathrm{C}\right)$ and large amounts of amylolytic enzymes need to be added, namely glucoamylase (EC 3.2.1.3) and $\alpha$-amylase. Non-cooking fermentation systems and low temperatures can reduce energy consumption by about $50 \%$, but large amounts of amylolytic enzymes still need to be added to hydrolyze starchy glucose material. Some researchers have reported attempts to solve this problem by using recombinant glucoamylase - yeast which can ferment starch directly into ethanol [1][15]-[22].

The method of directly converting starch into ethanol from wheat-rye bread waste using granular starch hydrolysis enzymes (GSHE) was reported by Pietrzak, 2014. In enzymatic hydrolysis, the liquefaction step is a costly process because it is carried out at high temperatures $(80-100 \circ C)$. Since glucoamylase takes a long time and temperatures are about $50-60^{\circ} \mathrm{C}$, the saccharification stage is also costly. GSHE is derived from aspergillus kawachii, a genetically modified a-amylase expressed in T. reesei and glucoamylase of T. reesei and exhibits the behavior of starch granules on the surface of a-amylase and glucoamylase. Previous research has shown that the performance of the direct conversion process from starch to ethanol is comparable to 'conventional technology' and the advantage is lower energy demand because it does not use the process of starch gelatinization and liquefaction. It has been shown that waste wheat-rye bread is a source of high ethanol yield for direct conversion to ethanol using GSHE, which delivers approximately $354 \mathrm{~g} / \mathrm{kg}$ of raw materials. On the other hand, the feeding of raw materials was relatively low, causing the effect of substrate and product inhibition on yeast cells smaller [15].

Another study by Bialas in 2010, They studied the complete use of the stillage in the repeated simultaneous saccharification and fermentation of cornflour for the preparation of ethanol. The result was presented that the yield of ethanol fermentation was not changed by the reutilizing of the stillage and the yield obtained was equivalent to $83.38 \%$ of the theoretical amount. In this work exhibit that a repeated batch SSF process conducted on starchy feedstock, using GSH enzymes, stands as an excellent choice for traditional technology in the production of fuel ethanol[16].

Other studies by Lamsal, 2012, studied the effect of corn preparation methods (flaking and grinding) on dry-grind ethanol performance using raw starch hydrolysis (RSH). Process use Novozyme RSH enzymes to conduct the BPX RSH single-saccharification and fermentation cycle for dry-ethanol. By $48 \mathrm{~h}$, starch hydrolysis was $81-88 \%$ for flaked-and-ground samples, including the control layer, and $64-73 \%$ for flakedonly samples, respectively. Ethanol profiles for flaked corn preparations are generally comparable to ground maize preparations given the 7-10 times larger flake sizes. Roller mill flaking, being a comparatively less energy-intensive (and easier) process, could be seen as an alternative to ground without affecting the production of ethanol in RSH technology. Corn flakes produced at roller mill gaps ranging from 0.203 to $0.508 \mathrm{~mm}$ were of greater magnitude than ground maize and had less degraded starch; however, they still had equivalent or better starch hydrolysis than ground maize [17].

Zhang, 2013, developed an energy-saving ethanol fermentation technology using uncooked fresh sweet potato (SSF) simultaneous saccharification and fermentation. They isolated an Aspergillus niger strain from mildewed sweet potato roots which generated high levels of enzymes from sweet potato to saccharify raw starch. Using this Aspergillus niger strain, the paste of uncooked fresh sweet potato storage roots was processed, and the processing of ethanol was then effectively carried out by $\mathrm{Z}$ mobilis. The concentration of ethanol in the supernatant fermentation increased after inoculation to $13.2 \%(\mathrm{v} / \mathrm{v})$ at $60 \mathrm{~h}$. In the production of fuel ethanol, uncooked fresh sweet potato roots were used which resulted in energy savings by avoiding a cooking phase and also had the benefit of reducing the viscosity of the fermentation paste. Aspergillus niger strain HQU- 
3 provided high RSGA levels for saccharification of starch and enzymes for further degradation of biopolymers. At high conversion rates, ethanol was provided by $\mathrm{Z}$ mobilis. The technology can be used to render raw sweet potato fuel with ethanol in an energy-saving and environmentally friendly manner [18].

Nichols et al., 2011, At the same time, various beans were saccharified and fermented using amylase, glucoamylase, and saccharomyces cerevisiae to ethanol. At the end of fermentation ( $72 \mathrm{~h}$ ), the concentrations of ethanol ranged from $3.5 \%(\mathrm{w} / \mathrm{v})$ for the fermentation of dark red kidney beans to $4.4 \%(\mathrm{w} / \mathrm{v})$ for pinto beans. The variability in the yield of ethanol per $\mathrm{g}$ beans was lower than the starch dependent variance since certain varieties of beans with lower starch content had higher starch conversion efficiencies. Conversion efficiency was the highest for pinto (94\%), navy $(98 \%)$, and northern $(100 \%)$ beans, a measure of ethanol produced as a percentage of the theoretical potential yield based on starch content. The possible yield of ethanol from beans indicates that ethanol is considered a co-product for another bean portion such as phytochemical extracts obtained from hulls, to follow a higher-value use. This research demonstrates that bean starch can be readily converted to ethanol using the same method and enzymes that are applied to corn. Beans can be staged with corn, presumably after extraction of usable ingredients. The protein fraction could be collected as a high-protein animal feed product after fermentation unless extracted and sold as an isolated product.[19].

A simultaneous saccharification and fermentation reaction was also studied by Dyartanti, 2015. They use white sorghum (Sorghum bicolor) as raw material. Beads biocatalyst was prepared by yeast (Saccharomyces cerevisiae) glucoamylase co-immobilization method in Na- $6 \%$. The biocatalyst is more stable, more bioethanol is made, and pollution is reduced. Total ethanol output at $\mathrm{Km}$ and $\mathrm{Vm}$ was $11.48 \%$, respectively $-0.0014 \mathrm{~g} / \mathrm{mL}$ and $0.00245 \mathrm{~g} / \mathrm{mL}$.hour. The purity of the starch in the white sorghum seeds increased by overnight soaking in $0.1 \mathrm{M}$ of $\mathrm{NaOH}$ solution [23].

Direct ethanol production from starch, wheat bran, and rice straw by the white-rot fungus Trametes birsuta has been investigated by Okamoto, et. al, 2010. T birsuta was grown in $20 \mathrm{~g} / \mathrm{L}$ starch, showing a maximum concentration of $9.1 \mathrm{~g} / \mathrm{L}$ ethanol after 96 hours of cultivation, $89.2 \%$ of the theoretical yield. In this case, during fermentation, the liberated glucose was found in the culture, suggesting that the starch had slowly decomposed. The direct conversion of ethanol from lignocellulosic biomass by the naturally occurring basidiomycete fungus will be a major advantage for the production of bioethanol through integrated bioprocessing because overall costs will be lower, the environmental footprint of production will be reduced and the use of hazardous chemicals will not be necessary [20].

Tanimura, 2015, studied direct ethanol production from starch using a natural isolate, Scheffersomyces shebatae. Quantitative assays showed that the strain showing the highest ethanol production capability was Scheffersomyces shehatae JCM 18690. This strain was able to directly use starch, and the concentration of ethanol was $9.21 \mathrm{~g} / \mathrm{L}$. We attribute this strain's ethanol-producing ability to high levels of glucoamylase activity, fermentation capacity, and resistance to ethanol stress. This study strongly suggests the possibility of the development of starch based ethanol by consolidated bioprocessing using natural yeasts like S. shehatae [21].

Xu, 2016, researched a novel raw starch-digesting glucoamylase PoGA15A with high enzymatic activity was purified from Penicillium oxalicum GXU20. The enzyme displayed surprisingly high $\mathrm{pH}$ stability $(\mathrm{pH}$ 2.0-10.5) and specificity of the substrates and was able to degrade different forms of raw starch at $40^{\circ} \mathrm{C}$. The capacity to adsorb various raw starches was consistent with its degrading capacities for the respective substrate. The enzyme encoding cDNA had been cloned and expressed heterological in Pichia pastoris. The recombinant enzyme could hydrolyse varying concentrations of raw corn and cassava flours $(50,100$, and $150 \mathrm{~g} / \mathrm{L}$ ) easily and efficiently with the addition of $\alpha$ amylase at $40^{\circ} \mathrm{C}$. In addition, when used in the simultaneous saccharification and fermentation of $150 \mathrm{~g} / \mathrm{L}$ raw flours to ethanol with the application of $\alpha$ amylase, the yield of ethanol reached $61.0 \mathrm{~g} / \mathrm{L}$ with a high fermentation efficiency of $95.1 \%$ after $48 \mathrm{~h}$ when the raw corn flour was used as the substrates. With raw cassava flour after $36 \mathrm{~h}$, an ethanol yield of $57.0 \mathrm{~g} /$ $\mathrm{L}$ and $93.5 \%$ fermentation efficiency was obtained. Its efficient raw starch hydrolysis and high efficiency during the direct conversion of raw corn and cassava flours by simultaneous saccharification and fermentation to ethanol suggest that the enzyme has a range of potential applications in industrial starch production and starch-based ethanol production [22].

In the same study done by Kheyrandish, 2015, the development of acetone-butanol-ethanol (ABE) from potato waste starch was conducted using free and immobilized cells. The starch was fermented directly to ABE Clostridium acetobutylicum without hydrolysis, and as a comparison, the results were compared with those obtained from glucose. The average yield of butanol from the waste starch and glucose was 0.21 and $0.26 \mathrm{~g}$ / g initial carbon source $(20 \mathrm{~g} / \mathrm{L})$, respectively. Batch fermentation of $60 \mathrm{~g} / \mathrm{L}$ of waste starch with free 
cells in a $5 \mathrm{~L}$ bioreactor resulted in the production of $9.9 \mathrm{~g} / \mathrm{L}$ butanol. A final butanol concentration of 15.3 $\mathrm{g} / \mathrm{L}$ was obtained in repeated batch fermentation using immobilized bacterium cells in calcium alginatepolyvinyl alcohol (PVA)-boric acid beads and $60 \mathrm{~g} / \mathrm{L}$ of the waste starch [14]. Similar to two-step ethanol production, direct ethanol production also commonly used $\alpha$-amylase and some combination of $\alpha-$ amylase with another one[15], [16], [19].

Table 1. Pre-treatment process from many starch source

\begin{tabular}{|c|c|c|c|c|c|}
\hline \multirow[b]{2}{*}{ Ref. } & \multirow[b]{2}{*}{ Starch source } & \multicolumn{3}{|c|}{ Pre-treatment } & \multirow[b]{2}{*}{ Ethanol yield } \\
\hline & & $\begin{array}{l}\text { Operation } \\
\text { condition }\end{array}$ & Enzyme & $\begin{array}{l}\text { Hydrolysis } \\
\text { Efficiency }\end{array}$ & \\
\hline \multicolumn{6}{|c|}{ Two Step Ethanol Production } \\
\hline$[9]$ & $\begin{array}{l}\text { Mixtures of } \\
\text { sweet sorghum } \\
\text { juice and } \\
\text { sorghum starch }\end{array}$ & $\begin{array}{l}\mathrm{T}=86^{\circ} \mathrm{C} \\
\mathrm{t}=1 \mathrm{~h} \\
\text { cooling } \mathrm{T} \\
=20^{\circ} \mathrm{C} \\
\mathrm{pH}=4.2\end{array}$ & $\begin{array}{l}\text { Liquozyme }{ }^{(} \mathrm{SC} C \mathrm{DS} \\
(\alpha-\text { amylase } 267 \\
\mathrm{KNU} / \mathrm{g}, 1.266 \mathrm{~g} / \mathrm{mL} ; \\
\text { Novozyme }\end{array}$ & $72 \%$ & $\begin{array}{l}20.25 \%(\mathrm{v} / \mathrm{v}) \text { of } \\
\text { ethanol }\end{array}$ \\
\hline$[10]$ & Corn starch & - & $\begin{array}{l}\alpha \text {-amilase, } \\
\text { glucoamylase }\end{array}$ & - & $20.3 \%$ ethanol \\
\hline$[11]$ & Cassava starch & $\begin{array}{l}\mathrm{T}=60^{\circ} \mathrm{C} \\
\mathrm{t}=4 \mathrm{~h}\end{array}$ & $\begin{array}{l}\alpha \text {-amylase and amylo- } \\
\text { glucosidase }\end{array}$ & - & $37.3 \%$ \\
\hline [12] & Cassava starch & $\begin{array}{l}\mathrm{T}= \\
160^{\circ} \mathrm{C}, \mathrm{t}= \\
2 \mathrm{~h}, \mathrm{P}=10 \\
\text { bar }\end{array}$ & $\mathrm{CC}-\mathrm{SO}_{3} \mathrm{H}$ catalyst & $100 \%$ & $15.41 \mathrm{~g} / \mathrm{L}$ \\
\hline [13] & Microalgal & - & $\begin{array}{l}\text { Cblamydomonas } \\
\text { reinbardtii }\end{array}$ & - & $0.87(\mathrm{~m} / \mathrm{v})$ \\
\hline$[15]$ & Waste bread & $\begin{array}{l}\mathrm{pH}=6, \\
150 \mathrm{rpm}, \mathrm{T} \\
=60^{\circ} \mathrm{C}, \mathrm{t} \\
=1 \mathrm{~h}\end{array}$ & $\begin{array}{l}\text { irect Ethanol Productic } \\
\alpha \text {-amylase, } \\
\text { glucoamylase, protease }\end{array}$ & - & $\begin{array}{c}354 \mathrm{~g} / \mathrm{kg} \text { of raw } \\
\text { materials }\end{array}$ \\
\hline [14] & $\begin{array}{l}\text { Potato waste } \\
\text { starch }\end{array}$ & $\mathrm{T}=37^{\circ} \mathrm{C}$ & Clostridium acetobutylicum & - & $\begin{array}{c}60 \mathrm{~g} / \mathrm{L} \text { of the waste } \\
\text { starch }\end{array}$ \\
\hline [16] & Corn & - & $\begin{array}{l}\alpha \text {-amylase and a } \\
\text { glucoamylase }\end{array}$ & - & $\begin{array}{c}83.38 \% \text { of the theoretic } \\
\text { al amount }\end{array}$ \\
\hline$[17]$ & Corn & $\begin{array}{l}\mathrm{T}=27 \mathrm{OC} \\
\mathrm{t}=48 \mathrm{~h}\end{array}$ & $\begin{array}{l}\text { Novozyme RSH } \\
\text { enzymes mix } 50009\end{array}$ & $81-88 \%$ & $19.1 \%(\mathrm{v} / \mathrm{v})$ \\
\hline [18] & $\begin{array}{l}\text { Uncooked } \\
\text { sweet potato } \\
\text { roots }\end{array}$ & - & RSGA & - & $13.2 \%(\mathrm{v} / \mathrm{v})$ \\
\hline [19] & $\begin{array}{l}\text { Dry common } \\
\text { beans }\end{array}$ & $\begin{array}{l}\mathrm{pH}=4.0- \\
4.5, \mathrm{~T}= \\
90^{\circ} \mathrm{C}\end{array}$ & $\begin{array}{l}\alpha \text {-amilase, } \\
\text { glucoamylase, cellulase, } \\
\text { protease }\end{array}$ & - & $3.5-4.4 \%(\mathrm{w} / \mathrm{v})$ \\
\hline$[20]$ & $\begin{array}{l}\text { Starch, wheat } \\
\text { bran, rice straw }\end{array}$ & - & Trametes hirsuta & - & $9.1 \mathrm{~g} / \mathrm{L}$ ethanol \\
\hline$[21]$ & Soluble starch & & Scheffersomyces shehatae & - & $9.21 \mathrm{~g} / \mathrm{L}$ \\
\hline$[22]$ & $\begin{array}{l}\text { Corn and } \\
\text { Cassava }\end{array}$ & $\mathrm{T}=40^{\circ} \mathrm{C}$ & Penicillium oxalicum & - & $57.0 \mathrm{~g} / \mathrm{L}$ \\
\hline$[23]$ & White shorgum & $\mathrm{T}=40^{\circ} \mathrm{C}$ & $\begin{array}{l}\alpha \text {-amylase, } \\
\text { glucoamylase }\end{array}$ & - & $0.0014 \mathrm{~g} / \mathrm{mL}$ \\
\hline$[24]$ & Sago waste & $\begin{array}{l}\mathrm{T}=40^{\circ} \mathrm{C} \\
\mathrm{t}=48 \mathrm{~h}\end{array}$ & Tapai yeast & - & $\begin{array}{c}7.24 \% \text { g ethanol / g } \\
\text { sago waste }\end{array}$ \\
\hline
\end{tabular}




\begin{tabular}{|c|c|c|c|c|c|}
\hline \multirow[b]{2}{*}{ Ref. } & \multirow[b]{2}{*}{ Starch source } & \multicolumn{3}{|c|}{ Pre-treatment } & \multirow[b]{2}{*}{ Ethanol yield } \\
\hline & & $\begin{array}{l}\text { Operation } \\
\text { condition }\end{array}$ & Enzyme & $\begin{array}{l}\text { Hydrolysis } \\
\text { Efficiency }\end{array}$ & \\
\hline [25] & $\begin{array}{l}\text { Corn flour and } \\
\text { hydrothermal } \\
\text { treated corn } \\
\text { stover mixture }\end{array}$ & $\begin{array}{l}\mathrm{T}=50^{\circ} \mathrm{C} \\
\mathrm{pH}=4.2\end{array}$ & $\begin{array}{l}\text { StargenTM002, } \\
\text { Accellerase } 1500\end{array}$ & - & higher than $37.9 \mathrm{~g} / \mathrm{L}$ \\
\hline [26] & Cassava starch & $\begin{array}{l}\mathrm{T}=35^{\circ} \mathrm{C}, \\
\mathrm{pH}=6.0, \mathrm{t} \\
=6 \text { days }\end{array}$ & $\begin{array}{l}\alpha \text {-amylase, } \\
\text { amyloglucosidase }\end{array}$ & - & $\begin{array}{l}84 \% \text { g ethanol / g } \\
\text { glucose consumed }\end{array}$ \\
\hline$[27]$ & $\begin{array}{l}\text { Mixed fruit } \\
\text { pulps banana } \\
\text { and mango }\end{array}$ & $\begin{array}{l}\mathrm{T}=60^{\circ} \mathrm{C} \\
\mathrm{pH}=6.0\end{array}$ & S. cerevisiae & $64.27 \%$ & $35.86 \%(\mathrm{w} / \mathrm{w})$ \\
\hline [28] & Maize starch & - & $\begin{array}{l}\text { high-amylose maize } \\
\text { starch, pullulanase }\end{array}$ & - & - \\
\hline [29] & Potato starch & $\begin{array}{l}\mathrm{T}=30^{\circ} \mathrm{C}, \\
\mathrm{t}=2 \mathrm{~h} \\
\text { acid } \\
\text { hydrolysis }\end{array}$ & & - & - \\
\hline$[30]$ & $\begin{array}{l}\text { Bagasse, } \\
\text { eucalyptus, and } \\
\text { cedar }\end{array}$ & $\begin{array}{l}\mathrm{T}=30^{\circ} \mathrm{C} \\
150 \mathrm{rpm}\end{array}$ & Saccharomyces cerevisiae & - & $0.81 \mathrm{~g} / \mathrm{L}$ \\
\hline
\end{tabular}

\section{Conclusion}

Ethanol production from starch requires a pre-treatment process before fermentation. There are two pretreatment processes i.e. two-step ethanol production and direct fermentation. Two-step ethanol production is a conventional method that separates pretreatment and fermentation process, while direct fermentation is the direct production of starch into ethanol using recombinant yeast that co-produces enzymes such as amylose and glucoamylase. Two-step ethanol production has the advantage high yield but need high cost whereas, direct fermentation has the advantage of low-cost production but needs longer time. Both of these processes can be run on average at temperatures of $30-80^{\circ} \mathrm{C}$ with a $\mathrm{pH}$ range of 4-6 and varying time intervals. The enzyme used depends on the source of the starch, but the most commonly and the best used are $\alpha$ amylase and combination of $\alpha$-amylase.

\section{References}

[1] A. Pandey, Ed., Handbook of Plant-Based Biofuels. CRC Press, 2009.

[2] Renewable Fuels Association, "Annual Ethanol Production.".

[3] F. and A. S. Nigro, Ethanol as a Fuel. Sao Paulo, Brazil: LL Sousa and IC Macedo, eds. Unica, 2011.

[4] P. S. Nigam and A. Singh, "Production of liquid biofuels from renewable resources," Prog. Energy Combust. Sci., vol. 37, no. 1, pp. 52-68, 2011, doi: 10.1016/j.pecs.2010.01.003.

[5] H. Zabed, J. N. Sahu, A. Suely, A. N. Boyce, and G. Faruq, "Bioethanol production from renewable sources: Current perspectives and technological progress," Renew. Sustain. Energy Rev., vol. 71, no. December 2016, pp. 475-501, 2017, doi: 10.1016/j.rser.2016.12.076.

[6] Japan Automobile Manufacturers Association Inc., "2016 REPORT ON ENVIRONMENTAL PROTECTION EFFORTS Promoting Sustainability in Road Transport in Japan,” p. 38, 2016.

[7] S. I. Mussatto et al., "Technological trends, global market, and challenges of bio-ethanol production," Biotechnol. Adv., vol. 28, no. 6, pp. 817-830, 2010, doi: 10.1016/j.biotechadv.2010.07.001.

[8] C. A. Barcelos, R. N. Maeda, G. J. V. Betancur, and N. Pereira, "Ethanol production from sorghum grains [Sorghum bicolor (L.) moench]: Evaluation of the enzymatic hydrolysis and the hydrolysate fermentability," Brazilian J. Chem. Eng., vol. 28, no. 4, pp. 597-604, 2011, doi: 10.1590/S010466322011000400005. 
[9] N. B. Appiah-Nkansah, K. Zhang, W. Rooney, and D. Wang, "Ethanol production from mixtures of sweet sorghum juice and sorghum starch using very high gravity fermentation with urea supplementation," Ind. Crops Prod., vol. 111, no. April 2017, pp. 247-253, 2018, doi: 10.1016/j.indcrop.2017.10.028.

[10] Z. Li, D. Wang, and Y. C. Shi, "Effects of nitrogen source on ethanol production in very high gravity fermentation of corn starch," J. Taiwan Inst. Chem. Eng., vol. 70, pp. 229-235, 2017, doi: 10.1016/j.jtice.2016.10.055.

[11] F. O. Ajibola, M. O. Edema, and O. B. Oyewole, "Enzymatic Production of Ethanol from Cassava Starch Using Two Strains of Saccharomyces cerevisiae," Niger. Food J., vol. 30, no. 2, pp. 114-121, 2012, doi: 10.1016/s0189-7241(15)30044-8.

[12] K. Intaramas, C. Sakdaronnarong, C. G. Liu, M. A. Mehmood, W. Jonglertjunya, and N. Laosiripojana, "Sequential catalytic-mixed-milling and thermohydrolysis of cassava starch improved ethanol fermentation," Food Bioprod. Process., vol. 114, pp. 72-84, 2019, doi: 10.1016/j.fbp.2018.11.011.

[13] M. J. Scholz, M. R. Riley, and J. L. Cuello, "Acid hydrolysis and fermentation of microalgal starches to ethanol by the yeast Saccharomyces cerevisiae," Biomass and Bioenergy, vol. 48, pp. 59-65, 2013, doi: 10.1016/j.biombioe.2012.10.026.

[14] M. Kheyrandish, M. A. Asadollahi, A. Jeihanipour, M. Doostmohammadi, H. Rismani-Yazdi, and K. Karimi, "Direct production of acetone-butanol-ethanol from waste starch by free and immobilized Clostridium acetobutylicum," Fuel, vol. 142, pp. 129-133, 2015, doi: 10.1016/j.fuel.2014.11.017.

[15] W. Pietrzak and J. Kawa-Rygielska, "Ethanol fermentation of waste bread using granular starch hydrolyzing enzyme: Effect of raw material pretreatment," Fuel, vol. 134, pp. 250-256, 2014, doi: 10.1016/j.fuel.2014.05.081.

[16] W. Białas, D. Szymanowska, and W. Grajek, "Fuel ethanol production from granular corn starch using Saccharomyces cerevisiae in a long term repeated SSF process with full stillage recycling," Bioresour. Technol., vol. 101, no. 9, pp. 3126-3131, 2010, doi: 10.1016/j.biortech.2009.12.090.

[17] B. P. Lamsal and L. A. Johnson, "Flaking as a corn preparation technique for dry-grind ethanol production using raw starch hydrolysis," J. Cereal Sci., vol. 56, no. 2, pp. 253-259, 2012, doi: 10.1016/j.jcs.2012.02.008.

[18] P. Zhang et al., "Starch saccharification and fermentation of uncooked sweet potato roots for fuel ethanol production," Bioresour. Technol., vol. 128, pp. 835-838, 2013, doi: 10.1016/j.biortech.2012.10.166.

[19] N. N. Nichols, N. Sutivisedsak, B. S. Dien, A. Biswas, W. C. Lesch, and M. A. Cotta, "Conversion of starch from dry common beans (Phaseolus vulgaris L.) to ethanol," Ind. Crops Prod., vol. 33, no. 3, pp. 644-647, 2011, doi: 10.1016/j.indcrop.2010.12.029.

[20] K. Okamoto, Y. Nitta, N. Maekawa, and H. Yanase, "Direct ethanol production from starch, wheat bran and rice straw by the white rot fungus Trametes hirsuta," Ensyme Microb. Technol., vol. 48, no. 3, pp. 273-277, 2011, doi: 10.1016/j.enzmictec.2010.12.001.

[21] A. Tanimura, M. Kikukawa, S. Yamaguchi, S. Kishino, J. Ogawa, and J. Shima, "Direct ethanol production from starch using a natural isolate, Scheffersomyces shehatae: Toward consolidated bioprocessing," Sci. Rep., vol. 5, 2015, doi: 10.1038/srep09593.

[22] Q. S. Xu, Y. S. Yan, and J. X. Feng, "Efficient hydrolysis of raw starch and ethanol fermentation: a novel raw starch-digesting glucoamylase from Penicillium oxalicum," Biotechnol. Biofuels, vol. 9, no. 1, pp. 1-18, 2016, doi: 10.1186/s13068-016-0636-5.

[23] E. R. Dyartanti, Margono, S. H. Pranolo, B. Setiani, and A. Nurhayati, "Bioethanol from sorghum grain (Sorghum bicolor) with SSF reaction using biocatalyst co-immobilization method of glucoamylase and yeast," Energy Procedia, vol. 68, pp. 132-137, 2015, doi: 10.1016/j.egypro.2015.03.241.

[24] K. C. Diong, G. C. Ngoh, A. Seak, and M. Chua, "Transformation of Starchy Lignocellulosic Biomass to Ethanol using Ragi Tapai Synergized with Microwave Irradiation Pretreatment," vol. 11, pp. 1991-2006, 2016.

[25] Y. Xu and D. Wang, "Integrating starchy substrate into cellulosic ethanol production to boost ethanol titers and yields," Appl. Energy, vol. 195, pp. 196-203, 2017, doi: 10.1016/j.apenergy.2017.03.035.

[26] S. Pervez, A. Aman, S. Iqbal, N. N. Siddiqui, S. Ali, and U. Qader, "Saccharification and liquefaction 
of cassava starch : an alternative source for the production of bioethanol using amylolytic enzymes by double fermentation process," pp. 1-10, 2014.

[27] R. Arumugam and M. Manikandan, "Fermentation of Pretreated Hydrolyzates of Banana and Mango Fruit Wastes for Ethanol Production," vol. 2, no. 2, pp. 246-256, 2011.

[28] B. Sun, Y. Tian, L. Chen, and Z. Jin, "Effect of acid-ethanol treatment and debranching on the structural characteristics and digestible properties of maize starches with different amylose contents," Food Hydrocoll., vol. 69, pp. 229-235, 2017, doi: 10.1016/j.foodhyd.2017.01.040.

[29] Z. qiang Fu, Y. Sun, Z. gang Huang, M. Wu, and Y. guang Zhou, "Effect of Acid-Alcohol Treatment on Physicochemical Properties of Ball-Milled Potato Starches," Starch/Staerke, vol. 71, no. 5-6, 2019, doi: 10.1002/star.201800347.

[30] R. Yamada et al., "Direct Ethanol Production from Ionic Liquid-Pretreated Lignocellulosic Biomass by Cellulase-Displaying Yeasts," Appl. Biochem. Biotechnol., vol. 182, no. 1, pp. 229-237, 2017, doi: 10.1007/s12010-016-2322-2. 